\section{Pacific Northwest}

National Laboratory

Operated by Battelle for the

U.S. Department of Energy

\title{
Phase I Source Investigation, Heckathorn Superfund Site, Richmond, California
}

N.P. Kohn

N.R. Evans

December 2002

Prepared for the U.S. Department of Energy under Contract DE-AC06-76RL01830 


\title{
DISCLAIMER
}

This report was prepared as an account of work sponsored by an agency of the United States Government. Neither the United States Government nor any agency thereof, nor Battelle Memorial Institute, nor any of their employees, makes any warranty, express or implied, or assumes any legal liability or responsibility for the accuracy, completeness, or usefulness of any information, apparatus, product, or process disclosed, or represents that its use would not infringe privately owned rights. Reference herein to any specific commercial product, process, or service by trade name, trademark, manufacturer, or otherwise does not necessarily constitute or imply its endorsement, recommendation, or favoring by the United States Government or any agency thereof, or Battelle Memorial Institute. The views and opinions of authors expressed herein do not necessarily state or reflect those of the United States Government or any agency thereof.

\author{
PACIFIC NORTHWEST NATIONAL LABORATORY \\ operated by \\ BATTELLE \\ for the \\ UNITED STATES DEPARTMENT OF ENERGY \\ under Contract DE-AC06-76RL01830
}

Printed in the United States of America

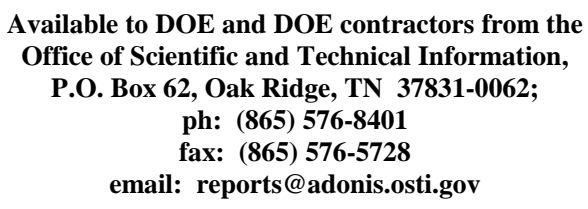

Available to the public from the National Technical Information Service, U.S. Department of Commerce, 5285 Port Royal Rd., Springfield, VA 22161 ph: (800) 553-6847 fax: $(703) 605-6900$

email: orders@ntis.fedworld.gov

online ordering: http://www.ntis.gov/ordering.htm 
PNNL-14088

UC-000

PHASE I SOURCE INVESTIGATION, HECKATHORN SUPERFUND SITE, RICHMOND, CALIFORNIA

\author{
N.P. Kohn
}

N.R. Evans

Battelle Marine Sciences Laboratory

Sequim, Washington

December 2002

Prepared for the

U.S. Environmental Protection Agency Region 9

under a Related Services Agreement with the U.S. Department of Energy under Contract DE-AC06-76RLO 1830

Pacific Northwest National Laboratory

Richland, Washington 


\section{SUMMARY}

The purpose of the present study is to identify the sources of dichlorodiphenyl trichloroethane (DDT) that have re-contaminated the sediment in Lauritzen Channel since remedial dredging in 1996 and 1997. The study reported here is Phase I of a phased approach to source investigation, in which the most likely DDT sources--outfall pipes and undredged channel sediment or unexcavated bank sediment--were investigated. Where possible, outfall pipes found during the Phase I survey were sampled for sediment and water. If present, sediment was collected directly from inside the mouth of the pipe; otherwise, a special sampler designed to trap particles from outfall discharge water was attached to the outfall pipe. To determine whether water flowing from outfall pipes carried significant quantities of pesticides into the channel, passive water samplers were placed in the end of the known outfall pipes. Passive water samplers and outfall sediment were analyzed for DDT and other pesticides of concern. Most of the identified outfalls are not considered a significant source of the DDT sediment contamination in Lauritzen Channel, but two of the outfalls bear further investigation: a concrete outfall found near Transect -8.5 and the 8-in. metal pipe outfall protruding from the retaining wall near Transect -28. The concrete pipe was discovered discharging a small volume of DDT-contaminated water during the March sampling, and may indicate a groundwater connection between upland bank soils and the channel. The 8-in. pipe could not be ruled out as a source: despite relatively low sediment concentrations, the passive sampler deployed there indicated exposure to high concentrations of DDT.

The undredged sediment under the Levin Pier and the northeast bank of Lauritzen Channel were evaluated in an underwater reconnaissance survey to document the present type, slope, and thickness of sediment under the Levin pier, and to identify potential sediment sampling locations. Thirty eight sediment samples were collected at locations of interest, both underwater in soft channel sediment and from intertidal or terrestrial soils on the embankment, and analyzed for DDT and other pesticides of concern. Bank soil samples collected from the channel bank near the north end of the Levin Pier contained higher concentrations of DDT than those previously found in channel sediments. The soft core collected at Transect +2.5 , beneath the north end of the Levin Pier, had the highest DDT concentration found yet in Lauritzen Channel sediment (23,190 ppm), more than 100 times higher than the highest concentrations found in surface sediment during the 1999 Sediment Investigation. Although the volume of soft sediment along the east bank was estimated to be relatively small, sediment core samples provide evidence for redistribution of undredged sediment from under the pier as a source of DDT contamination to the rest of Lauritzen Channel. However, it is the continuing contribution of upland bank material by erosion and possible groundwater leaching that warrants further investigation at the Heckathorn site. 


\section{ACKNOWLEDGMENTS}

The Phase I Source Investigation could not have been completed without the Battelle Marine Sciences

Laboratory (MSL) Dive Team, specifically Dive Team Captain John Southard and divers Greg Williams and Susan Sargeant. We also acknowledge the assistance and support of Andy Lincoff of EPA Region IX Laboratory, Remedial Project Manager Carmen White of EPA Region IX, and Elizabeth Vonckx, Tyler Gilmore, Deborah Coffey, Blythe Barbo, and Lee Miller of Battelle. 


\section{CONTENTS}

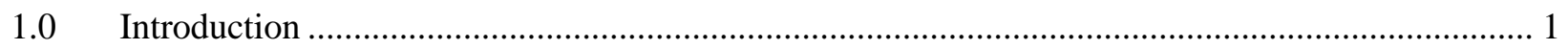

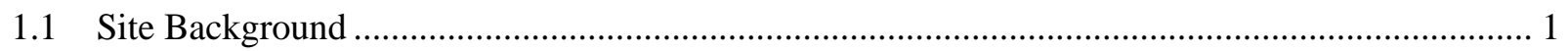

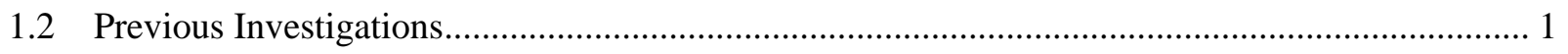

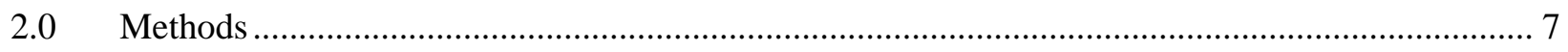

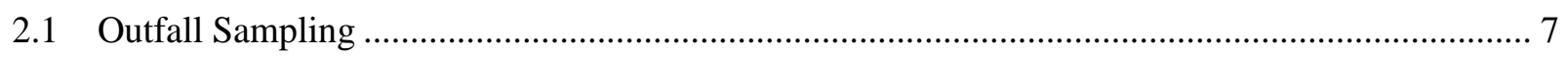

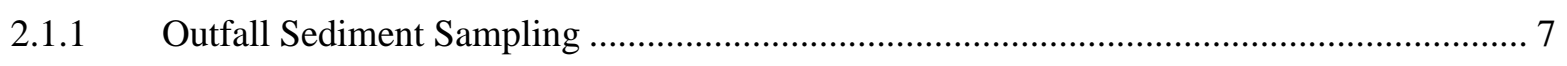

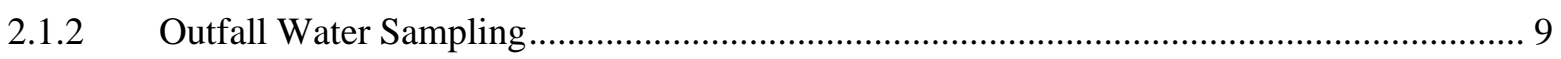

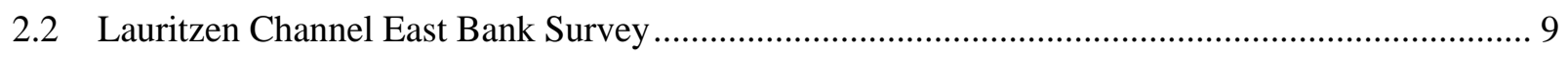

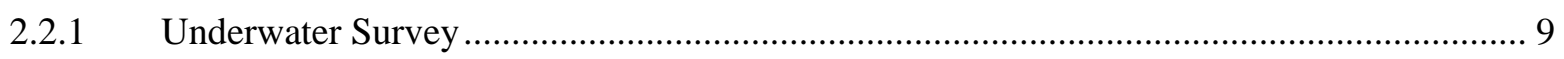

2.2.2 Sediment and Bank Soil Sample Collection................................................................ 12

2.2.3 Lauritzen Channel East Bank Survey Data Analysis .................................................. 16

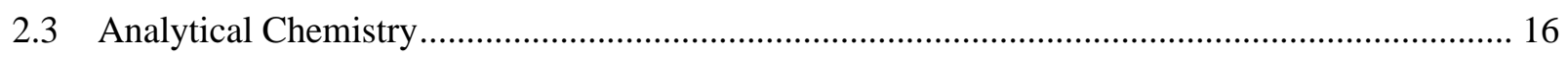

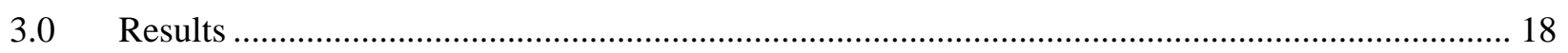

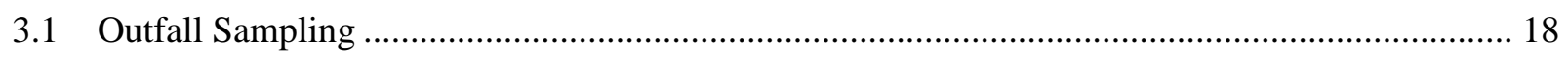

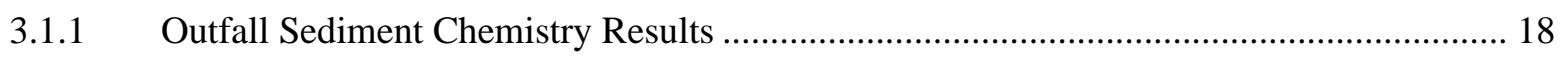

3.1.2 Outfall Water Chemistry Results............................................................................ 23

3.2 Lauritzen Channel East Bank Survey ................................................................................. 28

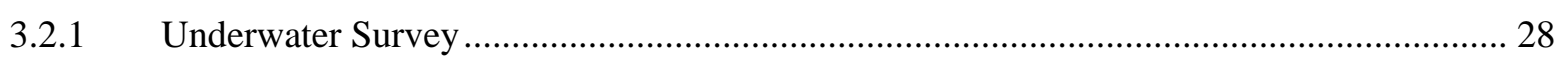

3.2.2 Soft Channel Sediment and Embankment Soil Chemistry ............................................ 48

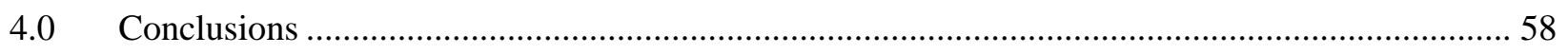

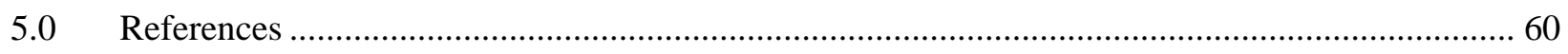

Appendix A Precipitation Monitoring During Outfall Sampler Deployment Appendix B EPA Field Report

Appendix C Sediment (Outfall, Core, and Bank) Sample Chemistry

Appendix D Passive Sampler and Water Chemistry 


\section{TABLES}

Table 3.1. Outfall Sampling Information, Heckathorn Phase I Source Investigation .............................19

Table 3.2. Chlorinated Pesticide Concentrations in Sediments In or Near Outfalls................................22

Table 3.3. DDT and Dieldrin Concentrations in Outfall Water and Passive Samplers Collected In or Near

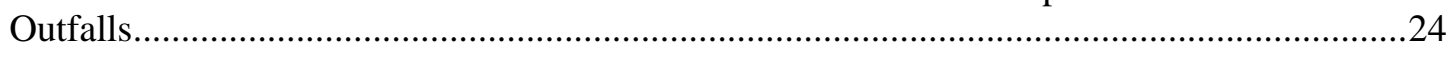

Table 3.4. Lauritzen Channel East Bank Underwater Survey Transect Data..........................................29

Table 3.5. Sample Collection Information for March 2002 Sediment and Bank Samples........................48

Table 3.6. Sample Collection Information for July 2002 Sediment Samples..........................................49

Table 3.6. Sample Collection Information for July 2002 Sediment Samples..........................................49

Table 3.7. Chlorinated Pesticide Concentrations in Lauritzen Channel East Bank Soils..........................50

Table 3.8. Chlorinated Pesticide Concentrations in Lauritzen Channel Soft Sediment Cores ...................51

Table 3.9. DDT and Dieldrin Concentrations in Additional Lauritzen Channel Sediment Samples

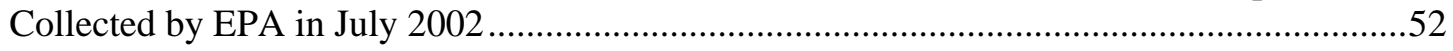




\section{FIGURES}

Figure 1-1. Location of the Heckathorn Superfund Site, Richmond, California ...................................... 2

Figure 1-2. Sample Locations and Results of Post-Remedial Monitoring Near the Heckathorn Site......... 3

Figure 1-3. Total DDT in Lauritzen Channel Surface Sediment (mostly Younger Bay Mud), 1999

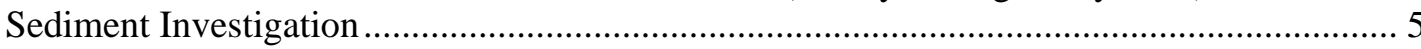

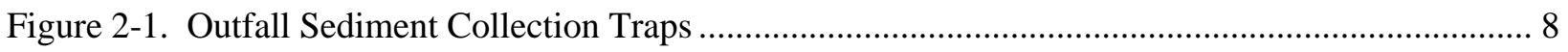

Figure 2-2. Lauritzen Channel East Bank Survey Transects ............................................................. 11

Figure 2-3. Conceptual Profile View of Underwater Survey Transect Beneath Levin Pier.................... 12

Figure 2-4. Lauritzen Channel East Bank Survey Sediment Sampling Locations, March 2002.............. 13

Figure 2-5. Lauritzen Channel (a) Soft Core and (b) Terrestrial Bank Soil Collection .......................... 14

Figure 2-6. Supplemental EPA Sediment Sampling Locations, July 2002 .......................................... 15

Figure 3-1. Outfall Water and Sediment Sampling Locations ............................................................. 20

Figure 3-2. Photodocumentation of Outfalls Discharging to Lauritzen Channel .................................... 21

Figure 3-3. Outfall Water and Sediment DDT Concentrations in Lauritzen Channel ............................ 26

Figure 3-4. Outfall Water and Sediment Dieldrin Concentrations in Lauritzen Channel ....................... 27

Figure 3-5. Bathymetry and Soft Sediment Thickness in the Underwater Survey Area ......................... 34

Figure 3-6. Typical substrate sequence under Levin Pier (from Transect +2.5 video) .......................... 36

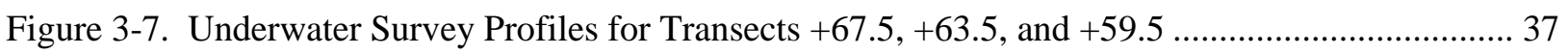

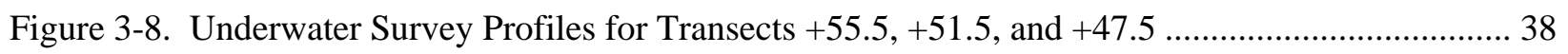

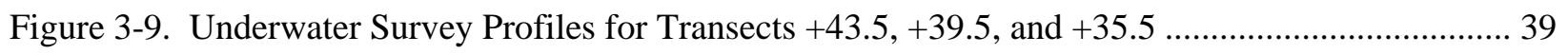

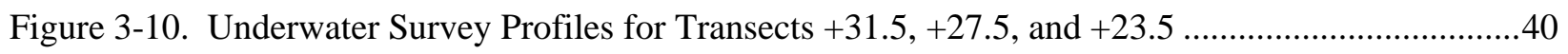

Figure 3-11. Underwater Survey Profiles for Transects $+19.5,+15.5$, and $+11.5 \ldots \ldots \ldots \ldots \ldots \ldots \ldots \ldots \ldots \ldots \ldots \ldots . . .41$

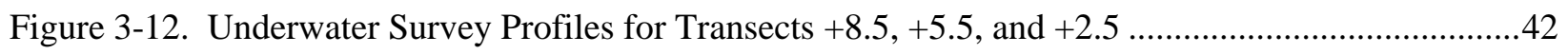

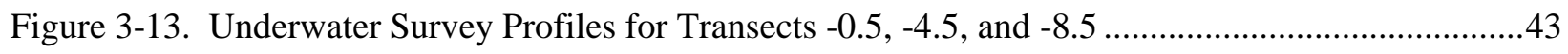

Figure 3-14. Underwater Survey Profiles for Transects -12.5 , -16.5 , and -20.5 ....................................4

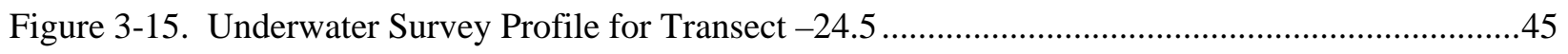

Figure 3-16. Exposed Shoreline North of Levin Pier, Lauritzen Channel East Bank ..............................46

Figure 3-17. Exposed Shoreline BeneathLevin Pier, Lauritzen Channel East Bank...............................47

Figure 3-18. DDT Concentrations in Sediment Core and Embankment Soil Samples Throughout Lauritzen Channel.

Figure 3-19. DDT Concentrations in Sediment Core and Embankment Soil Samples Concentrated in North Central Lauritzen Channel . .55

Figure 3-20. Dieldrin Concentrations in Sediment Core and Embankment Soil Samples Throughout Lauritzen Channel.

Figure 3-21. Dieldrin Concentrations in Sediment Core and Embankment Soil Samples Concentrated in North Central Lauritzen Channel 